\title{
An overview of distal tephrochronology in northern Europe during the last 1000 years
}

\author{
STEFAN WASTEGÅR ${ }^{1 *}$ and SIWAN M. DAVIES ${ }^{2}$ \\ ${ }^{1}$ Department of Physical Geography and Quaternary Geology, Stockholm University, Stockholm, Sweden \\ ${ }^{2}$ Department of Geography, School of the Environment and Society, Swansea University, Swansea, UK
}

Wastegård, S. and Davies, S. M. 2009. An overview of distal tephrochronology in northern Europe during the last 1000 years. J. Quaternary Sci., Vol. 24 pp. 500-512. ISSN 0267-8179.

Received 28 March 2008; Revised 12 January 2009; Accepted 14 January 2009

ABSTRACT: Several tephra layers from the last millennium have been identified in distal peat and lake sediment sequences in northern Europe, forming a framework of volcanic events of great value for palaeoenvironmental investigations. Most of the tephras within this framework have an origin in Iceland, but distal layers from Jan Mayen have also been identified. The predominant transport pathway, in an easterly-southeasterly direction, has led to the deposition of these tephras in a number of terrestrial deposits in northern Europe. Ash from silicic eruptions $\left(>63 \% \mathrm{SiO}_{2}\right)$ dominate at these sites, even though many of the documentary records in distal areas report tephra fall from several basaltic eruptions. Here we provide an overview of the distribution, shard concentration and geochemistry of these tephras to highlight the most important isochrones for addressing key dating issues. In particular, three horizons - Hekla-1 (AD 1104), Öræfajökull (AD 1362) and Askja (AD 1875) - are found at a number of different locations in northern Europe and as such are valuable tie-points for improving and validating chronological models and for synchronisation of records spanning the last 1000 years. In addition, we present new data identifying tephra from the Grímsvötn volcanic system within the Lomonosovfonna ice cap on Svalbard, demonstrating that some tephras have been transported $2000 \mathrm{~km}$ to as far north as $79^{\circ} \mathrm{N}$ along a northeasterly trajectory. This discovery highlights the potential for utilising tephrochronology as a correlation tool for palaeoarchives located in more northerly areas and the complex nature of fall-out from different eruptions. Copyright (C) 2009 John Wiley \& Sons, Ltd.

KEYWORDS: tephra; last millennium; tephrochronology; Europe; Grímsvötn.

\section{Introduction}

A key objective of palaeoclimate research is to examine lead and lag responses between different archives, which require synchronisation of proxy records on common timescales. Dating of recent sediments is often difficult due to fluctuations in atmospheric ${ }^{14} \mathrm{C}$ and requires several closely spaced samples for wiggle-matching to the calibration curve (Goslar et al., 2005). Other natural and artificial short-lived radioisotopes, such as ${ }^{210} \mathrm{~Pb}$ and ${ }^{137} \mathrm{Cs}$, can only be used for dating sediments spanning the last 100-150 a (e.g. Oldfield, 2005). The accuracy of age-depth models spanning the last millennium, however, can be tested by markers such as tephra layers from historically dated eruptions. As yet, for the last 1000 a this has mainly been achieved for areas proximal to the volcanic sources, and precise age-depth models have been constructed using a combination of radiometric methods and tephrochronology (Stihler et al., 1992; Boer et al., 2006). New methods have been developed for detecting small amounts of tephra in

* Correspondence to: S. Wastegård, Department of Physical Geography and Quaternary Geology, Stockholm University, SE-106 91 Stockholm, Sweden.

E-mail: stefan.wastegard@geo.su.se

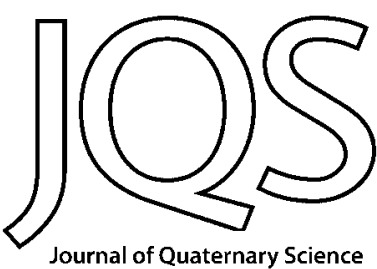

Journal of Quaternary Science distal areas, and these micro- or cryptotephra layers provide an opportunity for improving and validating chronological models and for producing precise tie-points between sparsely located records. Here we summarise the key tephras that can be used for improving chronological models and for precise correlation of different palaeoarchives in northern Europe spanning the last 1000 a.

In total, 205 eruptive events, with an average of 20-25 eruptions per century, have been identified within the volcanic history of Iceland over the last 1000 a (e.g. Thorarinsson and Sæmundsson, 1979; Thordarson and Larsen, 2007). Explosive volcanic eruptions where the products are partly or solely tephra are important for development of the volcanic history of Iceland, and some $65 \%$ of the eruptions in historical times have left tephra as the only evidence of the eruption (Larsen and Eiríksson, 2008). The Icelandic tephrochronology has been described in numerous papers since the pioneering work by Thorarinsson in the 1940s (e.g. Thorarinsson, 1944, 1951; Larsen, 1981; Larsen et al., 1999, 2001; Haflidason et al., 2000; Wastegård et al., 2003; Dugmore et al., 2007). The first descriptions of distal fallout of tephra from Icelandic eruptions are from documentary records (Connell, 1846; Mohn, 1878) and many of these observations were compiled by Thorarinsson (1981). It was not until the 1960s, however, that tephra 


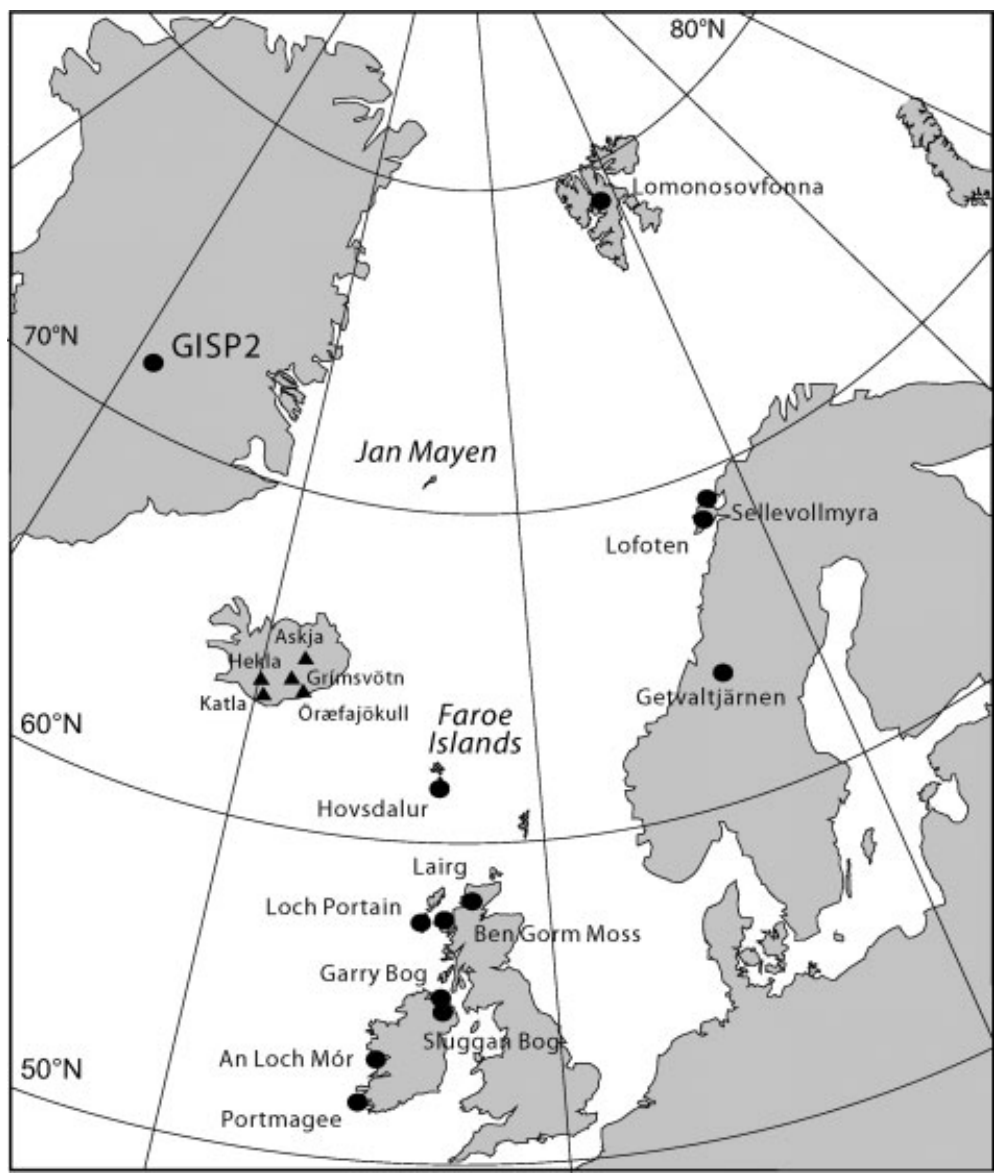

Figure 1 Map with place names in northwestern Europe mentioned in the text and volcanoes on Iceland and Jan Mayen, with the central volcano Mt Beerenberg

horizons were found to be more widespread, with their identification in more distal peat deposits on the Faroe Islands, Norway and Sweden (Persson, 1966, 1967, 1968) and some 20 years later on the British Isles (Dugmore, 1989; Pilcher and Hall, 1992).

At present, tephra layers from at least 16 volcanic events have been traced in distal locations in northern Europe (Fig. 1) and these form the framework outlined in this paper (Table 1). A predominant easterly-southeasterly transport pathway has led to the identification of these layers within peat and lacustrine deposits in Ireland, the British Isles and Scandinavia. In some instances volcanic material has also been carried northwards and westwards and has been traced within the Greenland ice cores and within marine records north of Iceland. Most of the tephra horizons identified in Table 1 are from silicic eruptions (>63\% SiO 2 ; Dugmore et al., 1995). Indeed three of the most widely dispersed tephras - Hekla-1 (AD 1104), Öræfajökull (AD 1362) and Askja (AD 1875) - are all of silicic geochemistry. Many of the documentary records, however, report tephra fall in western Norway and the Faroe Islands from basaltic eruptions, e.g. from the eruptions of Katla in AD 1625, 1660 and 1755 (Thorarinsson, 1981). These basaltic eruptions, however, have not left any traces in the sedimentary records outside Iceland possibly due to low concentrations of tephra (Dugmore and Newton, 1998) or as a result of post-depositional dissolution which particularly affects basaltic glass (Pollard et al., 2003; Wolff-Boenisch et al., 2004; Pollard and Heron, 2008). Up until now, only two basaltic tephras from the last 1000 a - Veiðivötn-1477 and Laki-1783 - have been traced in distal locations. We present new data demonstrating that basaltic material can be transported over large distances with tephra from the Grímsvötn volcanic system identified within an ice core retrieved from Svalbard. In addition, we provide an overview of those tephras from the last millennium that have been identified within terrestrial and ice palaeoarchives located outside of Iceland, and thus have the potential to be used for the synchronisation of records and for building chronological models. The distribution of tephra layers, shard concentration at each particular site and geochemistry of last-millennium tephras are reviewed to highlight those tephras of particular relevance for the last 1000 a.

\section{Tephrochronology framework for northern Europe over the last 1000 years}

\author{
MOR-T4 (ca. AD 1000), BGMT-1 (ca. AD 1120), \\ GB4-50 (ca. AD 1250)
}

The MOR-T4 and GB4-50 tephras have been found in single profiles in Ireland (Table 1), intercalated between more wellknown layers such as Hekla-1104 and Öræfajökull-1362 (Hall and Pilcher, 2002; Chambers et al., 2004). The BGMT-1 layer has also been found in a single site in Ben Gorm Moss on the Isle of Skye, western Scotland (Langdon and Barber, 2001), and consists of a mixed population of silicic tephra of Icelandic origin (Fig. 2(a) and (b)). Ages for these tephras are, in all cases, based on interpolation between radiocarbon dates and tephras of known ages and all layers have a geochemical affinity which suggest an Icelandic origin (Hall and Pilcher, 2002; Chambers et al., 2004). None of these tephras, however, have a known provenance or correlate with any other tephra or known 


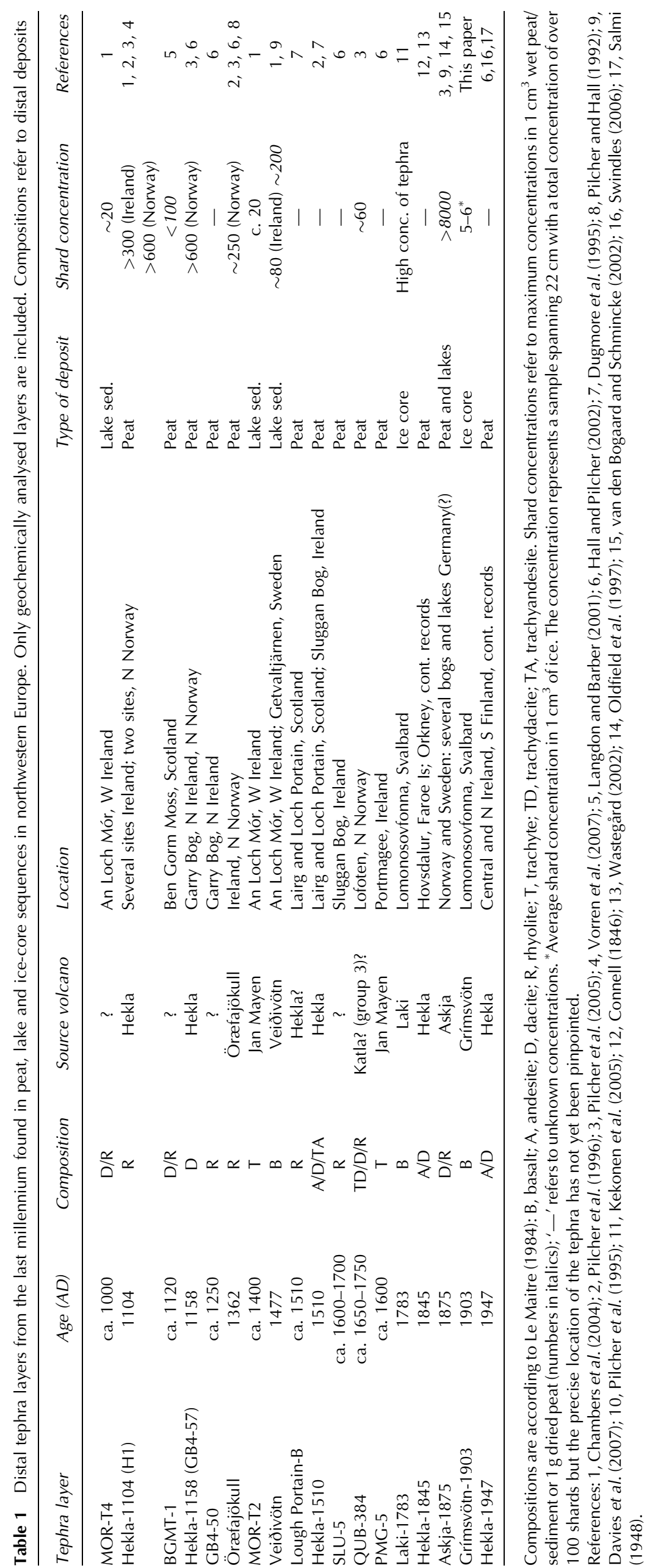



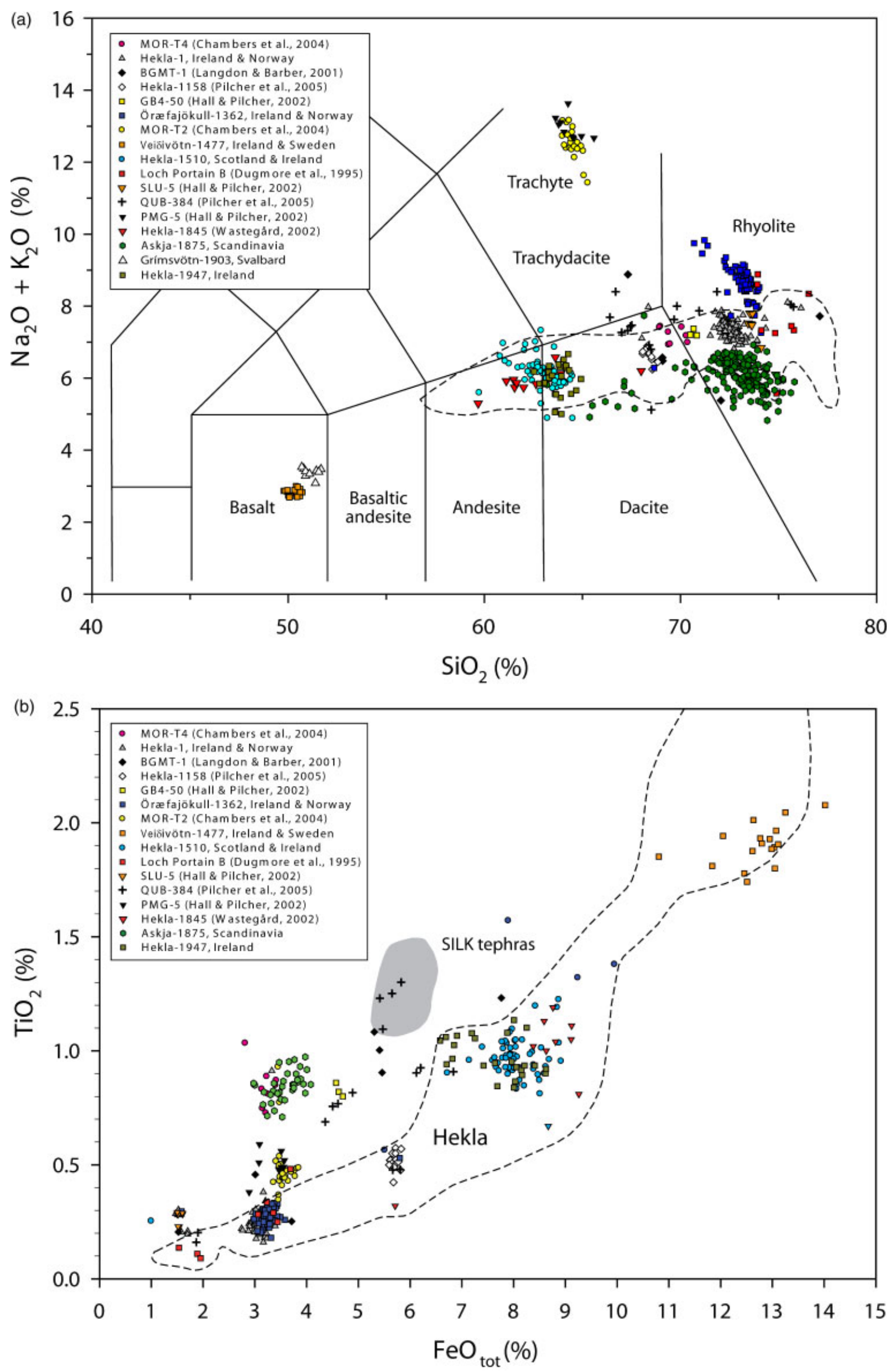

Figure 2 (Continued) 


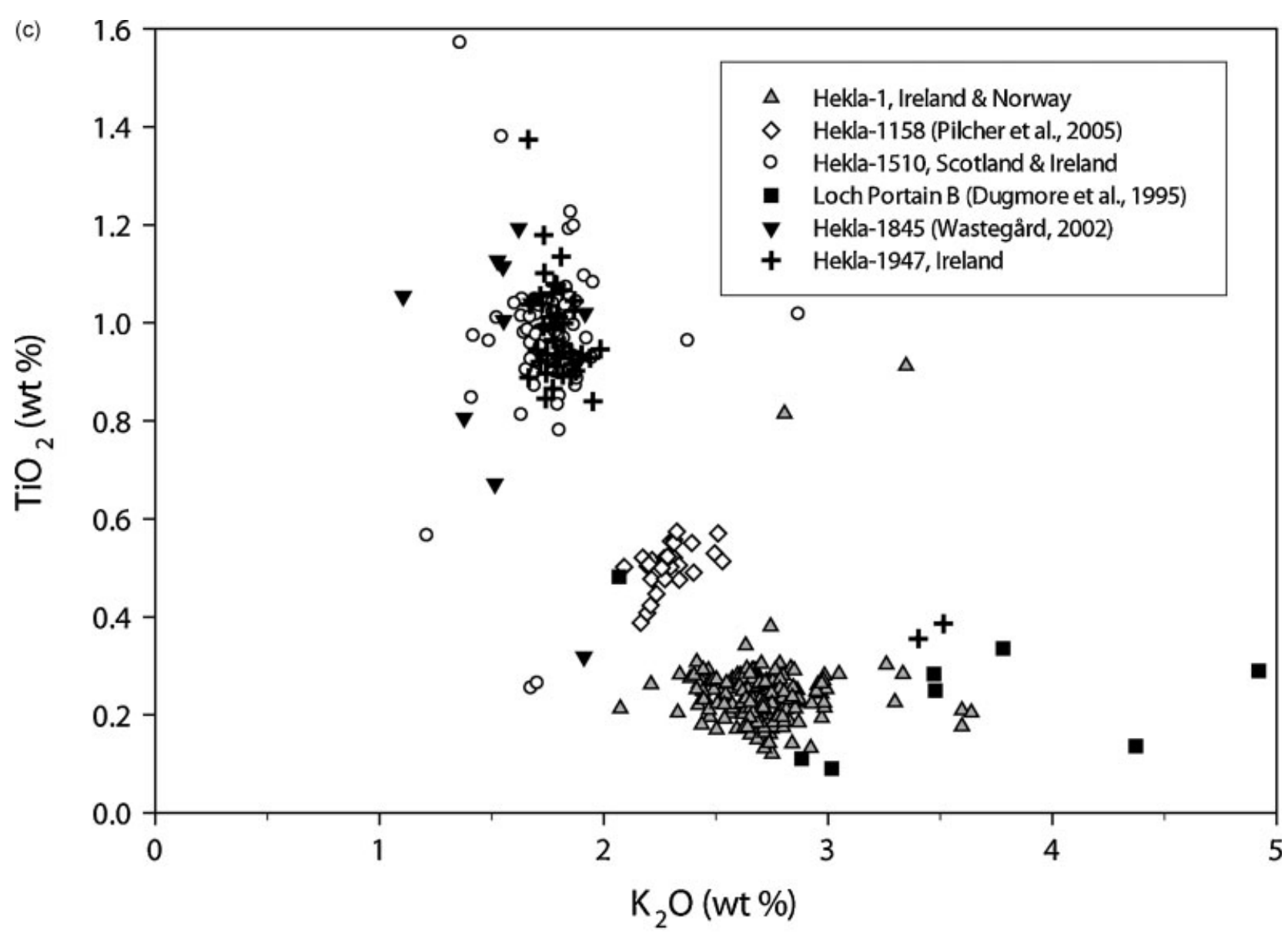

(d)

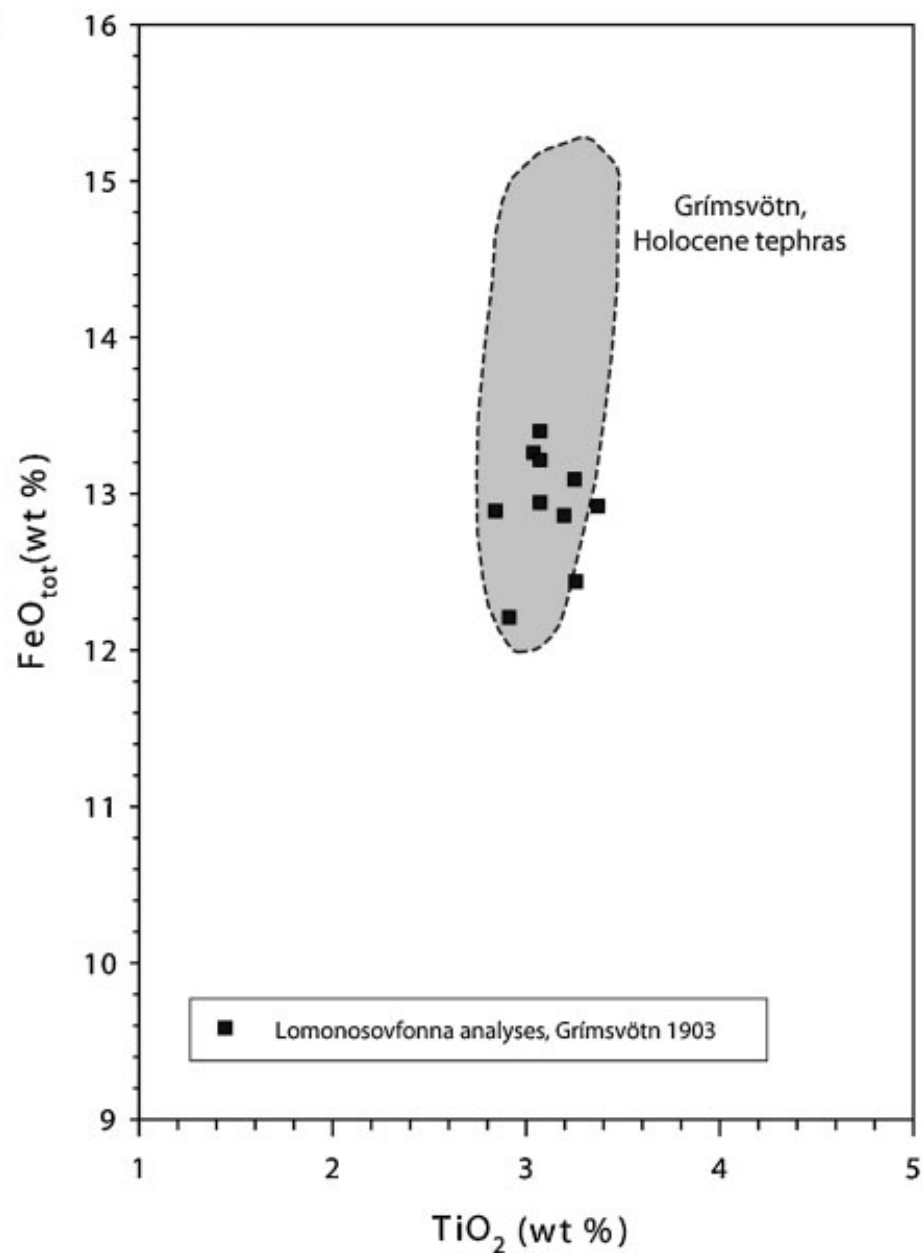

Figure 2 (a) Total alkali-silica biplot of distal tephra layers from the last millennium. (b) $\mathrm{FeO}_{\text {tot }}$ versus $\mathrm{TiO}_{2}$ of distal tephra layers from the last millennium. (c) $\mathrm{K}_{2} \mathrm{O}$ versus $\mathrm{TiO}_{2}$ of distal tephras from Hekla from the last millennium. (d) $\mathrm{FeO}_{\text {tot }}$ versus $\mathrm{TiO}_{2}$ of Grímsvötn-1903 from the Lomonosovfonna ice core; the shaded area shows the composition of Holocene tephras from Grímsvötn. All analyses have been normalised to $100 \%$. The dashed fields in (a) show the distribution of $\mathrm{SiO}_{2}$ versus $\mathrm{Na}_{2} \mathrm{O}+\mathrm{K}_{2} \mathrm{O}$ in all published Holocene tephras from Hekla (data from Tephrabase, www.tephrabase.org); compositional fields from Le Maitre (1984). The grey field in (b) shows the distribution of $\mathrm{FeO}_{\text {tot }}$ versus $\mathrm{TiO}_{2}$ in SILK tephra layers from Iceland and the Faroe Islands (Larsen et al., 2001; Wastegård, 2002; Óladóttir et al., 2008). Data points are from the following sources: MOR-T4 (Chambers et al., 2004); Hekla-1 (Pilcher et al., 1995, 1996, 2005; Hall and Pilcher, 2002; Chambers et al., 2004; Vorren et al., 2007); BGMT-1 (Langdon and Barber, 2001); Hekla-1158 (Hall and Pilcher, 2002; Pilcher et al., 2005); GB4-50 (Hall and Pilcher, 2002); Öræajökull1362 (Pilcher et al., 1995, 2005; Hall and Pilcher, 2002); MORT2 (Chambers et al., 2004); Veiðivötn-1477 (Chambers et al., 2004; Davies et al., 2007); Hekla-1510 (Dugmore et al., 1995; Pilcher et al., 1996; Swindles, 2006); Loch Portain B (Dugmore et al., 1995); SLU-5 (Hall and Pilcher, 2002); QUB-384 (Pilcher et al., 2005); PMG-5 (Hall and Pilcher, 2002); Hekla-1845 (Wastegård, 2002); Askja-1875 (Oldfield et al., 1997; Boygle, 2004; Bergman et al., 2004; Davies et al., 2007; Borgmark and Wastegård, 2008); Hekla-1947 (Hall and Pilcher, 2002; Swindles, 2006) 
Icelandic eruption during the early Medieval period. MOR-T4 and GB4-50 have similar geochemical signatures, but GB4-50 is considerably higher in $\mathrm{FeO}_{\text {tot }}$ (Fig. 2(b)) and lower in $\mathrm{MgO}$. Both tephras fall on the geochemical trend of the Hekla volcanic system as defined by the total alkali-silica biplot diagram (Fig. 2(a)); however, $\mathrm{FeO}_{\text {tot }} / \mathrm{TiO}_{2}$ ratios seem to exclude an origin in the Hekla volcanic system for both layers (Fig. 2(b)). Shard concentrations for MOR-T4 and BGMT-1 tephras are low (Table 1).

\section{Hekla-1 (Hekla-1104)}

The AD 1104 event was the largest Hekla eruption in historical times (Thorarinsson, 1967) and the associated tephra layer is one of the most important isochrones in terrestrial and marine records on Iceland (Larsen and Thorarinsson, 1977; Boygle, 1999; Larsen et al., 1999, 2002) and more distal sites in Europe (Pilcher et al., 1996, 2005; Chambers et al., 2004; Vorren et al., 2007). This tephra can be separated from other historical Hekla tephras in plots of $\mathrm{K}_{2} \mathrm{O} / \mathrm{TiO}_{2}$ (Fig. 2(c)) and is more evolved than any other historical tephra from Hekla (Larsen et al., 1999). The main distribution was to the north, making this layer one of the most important Holocene markers in marine records north of Iceland (Eiríksson et al., 2000; Larsen et al., 2002; Kristjansdottir et al., 2007). Hekla-1 is one of the most widespread Holocene tephras from Iceland and was reported in Scandinavian peat bogs as early as the 1960s (Persson, 1966). Persson's records were not confirmed by geochemical analyses, however, and it was not until recently that the Hekla-1 was securely identified in sequences in Scandinavia (Pilcher et al., 2005; Vorren et al., 2007). This tephra is also the most reported historic tephra in Ireland (Pilcher et al., 1996; Hall and Pilcher, 2002; Chambers et al., 2004), and has been used to constrain timeframes for climate and human impact studies of Irish bogs (Hall, 2003; Hall and Mauquoy, 2005). While abundant on Ireland, Hekla-1 seems to be absent in many other parts of northwestern Europe, including Scotland, England, Germany and southern Scandinavia. Maps showing the distribution of Hekla 1104 indicate a main dispersal to the north (Thorarinsson, 1967; Larsen et al., 1999), which could explain the occurrence in northern Norway. However, plumes with tephra must have been directed also to the south towards Ireland during part of the eruption. Thus the distribution of Hekla-1 may be confined to areas with high precipitation, such as northwestern Norway and Ireland, suggesting a possible link between high precipitation and tephra deposition (Langdon and Barber, 2004).

\section{Hekla-1158}

Another eruption of Hekla occurred a few decades after the Hekla-1 eruption and, together with Hekla-1, these are the only historical eruptions of Hekla where silicic tephra has been produced (Fig. 2(a)). Hekla-1158 had a smaller volume of erupted tephra than Hekla-1 and significantly lower $\mathrm{SiO}_{2}$ and higher $\mathrm{FeO}_{\text {tot }}$ concentrations (Fig. 2(a) and (b); Larsen et al., 1999). The main dispersal was to the northeast (Thorarinsson, 1967; Larsen et al., 1999) and Hekla-1158 was recently reported from northern Norway (Pilcher et al., 2005). In addition, a tephra layer found in the Garry bog in Ireland, GB457, dated approximately to $1150 \mathrm{AD}$ has a geochemistry identical to Hekla-1158 (Hall and Pilcher, 2002) and suggests that this tephra was also transported southwards. Hekla-1158 can be distinguished from Hekla-1 on total silica-alkali plots and plots of $\mathrm{FeO}_{\text {tot }}$ versus $\mathrm{TiO}_{2}$ or $\mathrm{K}_{2} \mathrm{O}$ versus $\mathrm{TiO}_{2}$ (Fig. 2(a)(c)). Shard concentrations in northern Norway are reported to be relatively high for Hekla-1 and Hekla-1158 (Table 1).

\section{Öræfajökull-1362}

The explosive rhyolitic eruption of Öræfajökull in June 1362 was the most voluminous silicic eruption in historical times in Iceland (Thorarinsson, 1958; Palais et al., 1991). According to investigations in distal areas, including Scandinavia, Ireland (Pilcher and Hall, 1992; Pilcher et al., 1996, 2005) and Greenland (Palais et al., 1991), large volumes of tephra from this eruption were blown in different directions (Fig. 3(b)). Three main distribution plumes have been reconstructed based on these distal occurrences. Despite being identified in a number of sites in Ireland (Pilcher and Hall, 1992; Pilcher et al., 1996), Öræfajökull-1362 is yet to be found in Britain. Tephra from all these areas have a uniform composition characterised by high $\mathrm{Na}_{2} \mathrm{O}$ and very low $\mathrm{MgO}$ contents (Larsen et al., 1999; Selbekk and Trønnes, 2007).

\section{MOR-T2}

This tephra is the youngest of four layers found in the lacustrine sediments of the karstic lake An Loch Mór, western Ireland, with a geochemical signature suggesting an origin on Jan Mayen, i.e. a trachytic composition with high $\mathrm{Na}_{2} \mathrm{O}$ and $\mathrm{K}_{2} \mathrm{O}$ (Fig. 2(a); Chambers et al., 2004). MOR-T2 is dated by interpolation to ca. AD 1400. It is possible that MOR-T2 can be correlated with the PMG-5 layer (see below). The central volcano on Jan Mayen, Mt Beerenberg, which has erupted at least three times during the last $1000 \mathrm{a}-1732,1818$ and 1970 (e.g. Sylvester, 1975) - has been pinpointed as a potential source for this tephra. The shard concentration is low (Table 1).

\section{Veiðivötn-1477}

One of the most explosive eruptions in historical time on Iceland was the eruption of Veiðivötn in 1477, which produced a tephra volume of more than $5 \mathrm{~km}^{3}$ (Larsen, 1984; Larsen and Eiríksson, 2008). The Veiðivötn-Bárdarbunga volcanic system is one of the most productive volcanic systems in Iceland, with at least 60 identified tephra layers from the last $10 \mathrm{ka}$ (Larsen and Eiríksson, 2008). Tephra from the 1477 eruption of Veiðivötn has been found in marine cores north of Iceland (Larsen et al., 2002), and basaltic tephra layers of similar age have been traced in Lake Getvaltjärnen in west central Sweden (Davies et al., 2007) and the An Loch Mór lake in western Ireland (Chambers et al., 2004). Both layers have a tholeiitic composition and plots of $\mathrm{SiO}_{2} / \mathrm{K}_{2} \mathrm{O}+\mathrm{Na}_{2} \mathrm{O}$ (Fig. 2(a)), for example, suggest an origin in the Veiðivötn fissure swarm in the Eastern Volcanic Zone in Iceland (Chambers et al., 2004; Davies et al., 2007). It is more than likely that the tephra layers reported from Ireland and Sweden are from the widespread eruption of 1477 , but other eruptions close in age and geochemical signature, e.g. AD 1410 and 1717, are also possible candidates and fall within the error margins of the agedepth models for these sites (Chambers et al., 2004; Davies et al., 2007). Since Veiðivötn is one of the most productive systems on Iceland, further evidence, such as other tephra layers or radiocarbon dates, is required to support the identity of the 1477 eruption. 
(a)

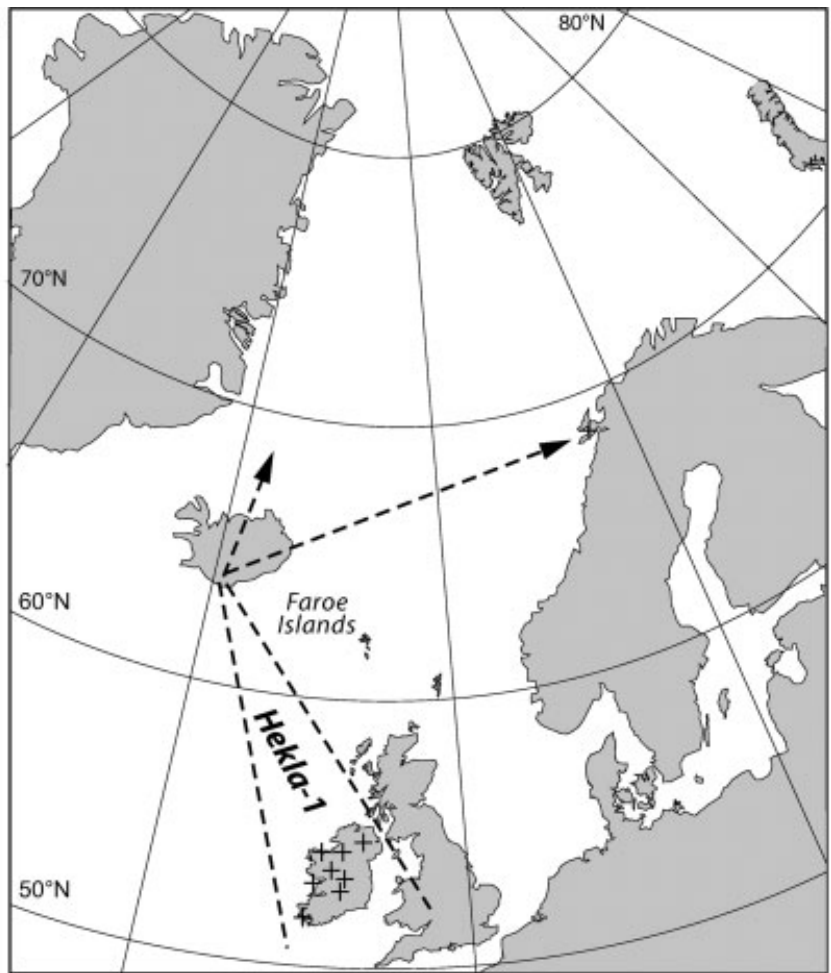

(c)

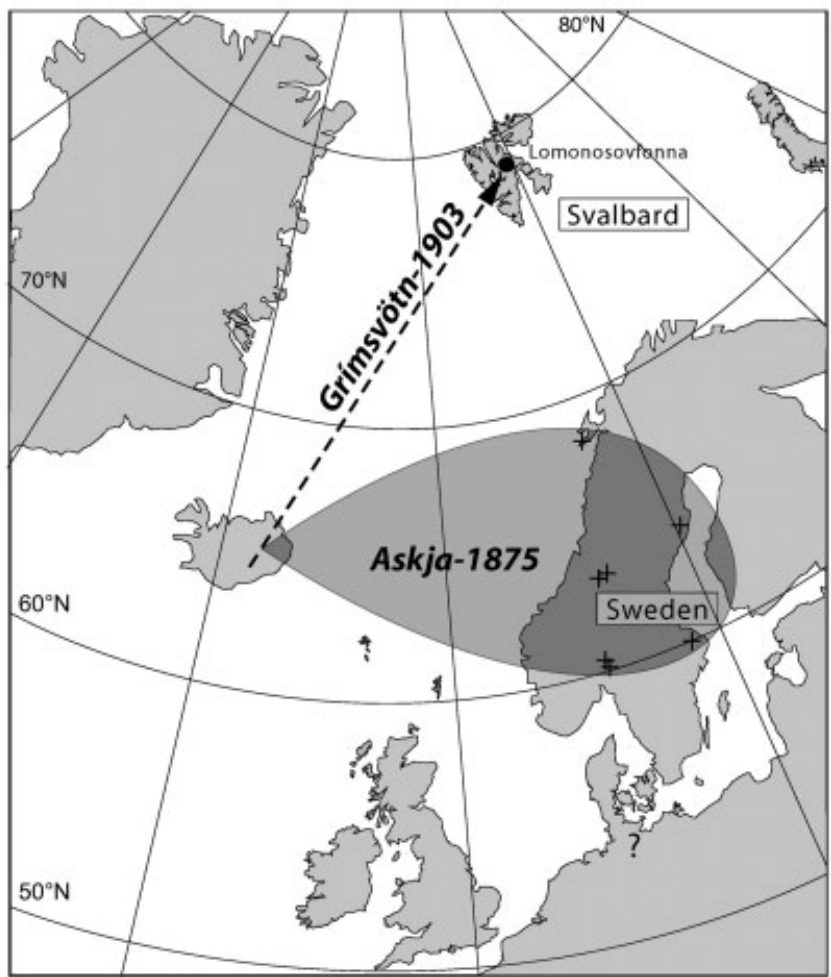

(b)

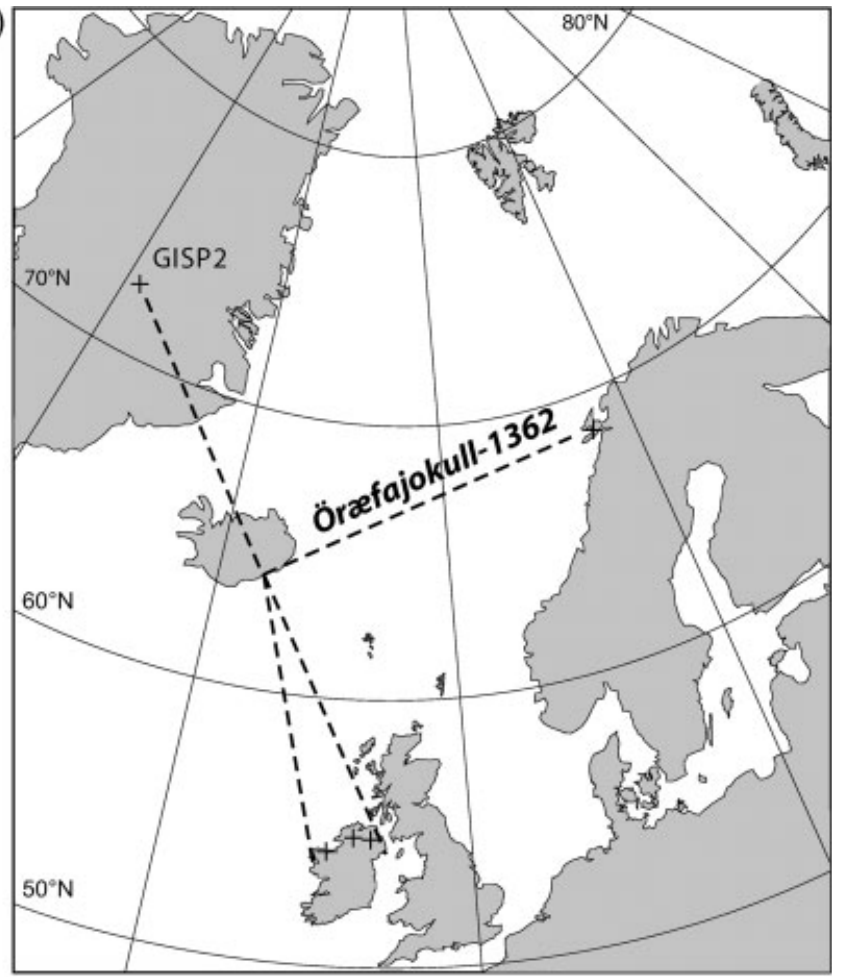

(d)

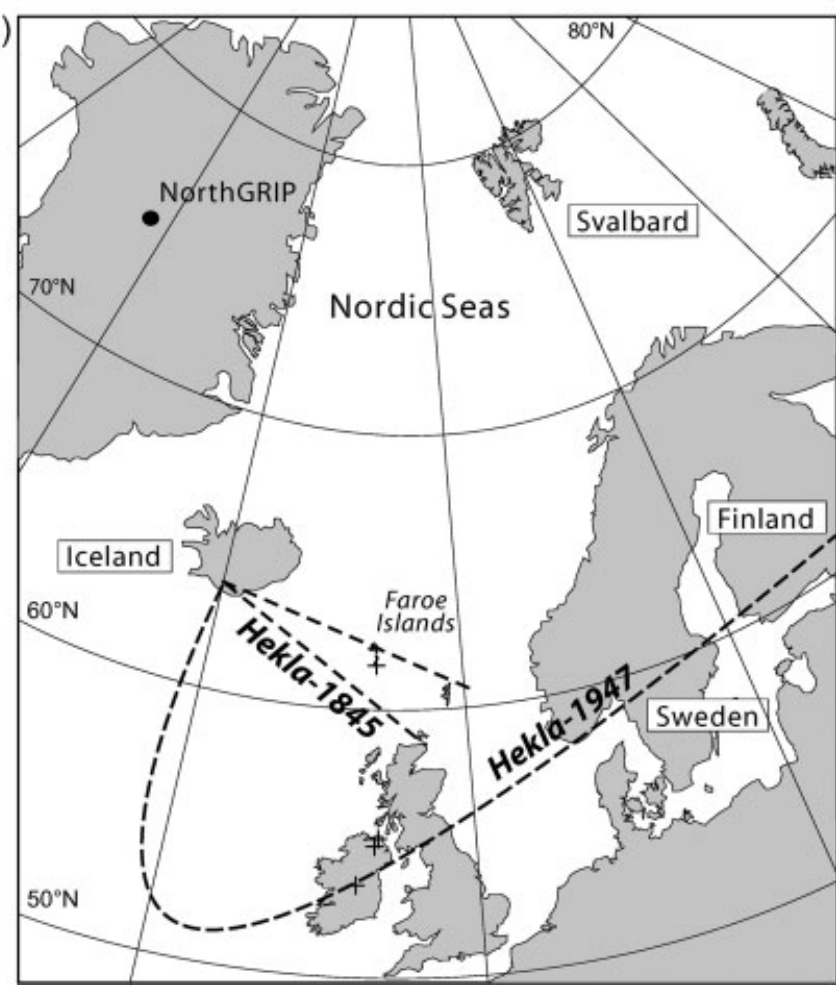

Figure 3 Map series showing examples of distal tephra fallout from Icelandic eruptions during the last 1000 a. Confirmed records are marked by + . (a) Hekla-1; (b) Öræfajökull-1362; (c) Askja-1875 and Grímsvötn-1903; (d) Hekla-1845 and Hekla-1947

\section{Hekla-1510}

Tephra from the relatively small eruption of Hekla in 1510 was one of the first Holocene tephra layers described from the British Isles (Dugmore et al., 1995, 1996; Pilcher et al., 1996) but as yet this tephra has not been found in continental Europe. Unlike most other historical eruptions from Hekla, the main axis of distribution was to the southwest (Thorarinsson, 1967; Larsen et al., 1999), which could explain the absence of Hekla 1510 in Scandinavian sites.
The early erupted tephra of Hekla 1510 is nearly identical in major element geochemistry to the Hekla-1947 tephra (Fig. 2(a)-(c)). Two groups with different geochemical signatures occur in Scottish deposits: one with (trachy)andesitic to dacitic composition (Fig. 2(a)) securely correlated with Hekla-1510 (Loch Portain A) and another highly evolved rhyolitic group (Fig. 2(a); Loch Portain B) that may either represent the earliest phase of the Hekla eruption or may derive from another eruption closely spaced in time (Dugmore et al., 1995). 
Tephras from the 1600s-1700s (QUB-384, SLU5 and PMG-5)

Several tephra layers dated to the 17 th and 18 th centuries have been found in bogs in Ireland and northern Norway (Hall and Pilcher, 2002; Pilcher et al., 2005). Low concentrations of tephra from this time period have also been reported from bogs in Sweden, but it has not been possible to analyse them geochemically (Borgmark and Wastegård, 2008). All layers have an Icelandic provenance, except the PMG-5 layer found in the Portmagee bog in south-western Ireland (Hall and Pilcher, 2002). This layer has a similar trachytic composition to the MOR-T2 layer found in the An Loch Mór, western Ireland, suggesting a Jan Mayen origin (Fig. 2(a); Chambers et al., 2004). The 'QUB-384, group 3' tephra found in Lofoten (Pilcher et al., 2005) has a dacitic to trachydacitic composition and many analyses are similar to the silicic SILK tephras erupted from Katla during the Holocene (Fig. 2(b); Larsen et al., 2001; Wastegård, 2002) and might represent a previously unknown silicic component from one of the eruptions of Katla that was reported from documentary or historical records in Norway; for example, the major eruption in 1755 that produced more tephra than any other historical eruption of Katla (Thorarinsson, 1981; Larsen et al., 2001).

\section{Laki-1783}

The Laki fissure eruption lasted for 8 months in 1783-1784 and produced one of the largest lava flows in Iceland (Thordarson and Self, 2003). The eruption emitted 122 megatons of $\mathrm{SO}_{2}$ and caused an aerosol-forced cooling in Europe and other regions, followed by crop failure and increased mortality (Stothers, 1996; Witham and Oppenheimer, 2004). A strong sulphate peak identified in many ice cores from Greenland, Svalbard and the Alps has been connected to the Laki eruption (Clausen and Hammer, 1988; Fiacco et al., 1994; Zielinski et al., 1994; Schwikowski et al., 1999) and glass particles have been reported from the GISP2 ice core (Fiacco et al., 1994) and the Lomonosovfonna ice core from Svalbard (Kekonen et al., 2005). However, only one glass particle was analysed from the Lomonosovfonna ice core, which precludes a detailed comparison to the Laki type site material (Kekonen et al., 2005).

\section{Hekla-1845}

The 13th eruption of Hekla in historical time started in September 1845 and went on continuously until April the following year (Thorarinsson, 1967). The preceding repose time was 79 a and tephra from the initial phase was blown towards the southeast and was recorded overseas in Orkney, Shetland and the Faroe Islands, according to documentary records (Connell, 1846; Thorarinsson, 1981). Ash fell on 3 September on the southernmost of the Faroe Islands, Suduroy, according to contemporary records (Guttesen, pers. comm. 2007). Subsequent geochemical analyses from Hovsdalur on Suduroy (Fig. 1; Wastegård, 2002) have confirmed ash fallout, tentatively correlated with Hekla-1845 (Fig. 3(d)). These analyses show an andesitic composition, similar to Hekla-1510 and Hekla1947 (Fig. 2(a)-(c)). Most shards have lower $\mathrm{SiO}_{2}$ and higher $\mathrm{FeO}_{\text {tot }}$ (Fig. 2(a) and (b)), but the differences are too small to allow these tephras to be separated on the basis of single shard microprobe analyses.
Askja-1875

The explosive rhyolitic eruption of Askja in March 1875 lasted for a few hours and produced a light-coloured tephra layer east of the Askja caldera in eastern central Iceland (Sigvaldason, 2002). Due to strong westerly winds during the eruption, tephra was transported to the east (Fig. 3(c)), reaching the coast of western Norway $\sim 15 \mathrm{~h}$ later and Stockholm $\sim 26 \mathrm{~h}$ later (Mohn, 1878). The rhyolitic Askja-1875 tephra is distinguished from other historic tephras with comparable $\mathrm{SiO}_{2}$ concentrations by relatively high $\mathrm{MgO}(0.55-0.75 \%)$ and $\mathrm{TiO}_{2}(0.70-0.85 \%$; Fig. 2(b)) percentages (Larsen et al., 1999; Boygle, 2004; Davies et al., 2007). It was tentatively recorded in peat bogs in Norway and Sweden (Persson, 1966, 1967) and later geochemical analyses have confirmed the occurrence of Askja-1875 in the area indicated by Mohn (1878) from documentary records (Boygle, 2004; Davies et al., 2007; Borgmark and Wastegård, 2008). Several records in Scandinavia have very high concentrations with several thousand shards $\mathrm{cm}^{-3}$ (e.g. Davies et al., 2007; Borgmark and Wastegård, 2008). A recent record from Lofoten Islands, northern Norway (Pilcher et al., 2005), extends the area of distribution further to the north but a tentative record from northern Germany needs to be confirmed by further analyses (van den Bogaard and Schmincke, 2002).

\section{Grímsvötn-1903}

A recent addition to the framework of distal tephra layers is the Grímsvötn-1903 eruption. Geochemical analysis of a basaltic tephra horizon identified in the Lomonosovfonna ice core from Svalbard (Fig. 1; Isaksson et al., 2001) points towards Grímsvötn as the most likely source. Ten shards from this horizon exhibit $\mathrm{TiO}_{2}$ concentrations between $2.8 \%$ and $3.2 \%$ and $\mathrm{FeO}_{\text {tot }}$ concentrations around $13 \%$ (Fig. 2(d); Tables 2 and 3), suggesting an origin in the Grímsvötn volcanic system of southeastern Iceland (Fig. 1; Larsen, 1981). The geochemical composition is similar to other tephras from the Grímsvötn system, and major element composition cannot distinguish between tephra from different eruptions. The age model for this ice core, based on an ice layer thinning model and key reference horizons (e.g. the Laki-1783 event and the 1963 radioactive layer; Kekonen et al., 2005), gives an age of around 1900 for the ice surrounding the tephra. Consequently, the most likely eruption is Grímsvötn 1903 based on the amount of tephra produced and the easterly-northeasterly direction of tephra dispersal (Larsen, pers. comm. 2008). The most intense period of tephra production occurred during the first 2 days of the eruption and tephra deposition was reported from a ship 30 miles east of the Icelandic coast.

\section{Hekla-1947}

The course of the tephra from the 1947 eruption of Hekla has been reconstructed from contemporary records, including ash fall on ships in the North Atlantic and fallout in southern Finland (Thorarinsson, 1954). An early phase of andesitic tephra was transported to the south-southwest, followed by a later phase of dacitic tephra to the south (Fig. 3(c)) (Thorarinsson, 1954; Kirkbride and Dugmore, 2003). Tephra of andesitic/dacitic composition was recently found in three bogs in Ireland (Hall and Pilcher, 2002; Swindles, 2006), and it is possible that ash fall may also have occurred along the course of the tephra cloud in Scotland, Norway and Sweden, but tephra has so far not been 
Table 2 Major oxide percentages in tephra from the Lomonosovfonna core, determined by electron microprobe analyses. Analytical totals below 93\% have been discarded. The tephra horizons were prepared for electron microprobe analysis using wavelength dispersive spectrometry (WDS). The samples were analysed with a Cameca SX100 electron microprobe equipped with five vertical WD spectrometers. Eleven major elements were measured with a counting time of $10 \mathrm{~s}$. An accelerating voltage of $10 \mathrm{kV}$, beam strength of $10 \mathrm{nA}\left(3 \mathrm{nA}\right.$ for $\mathrm{SiO}{ }_{2}$ and $\left.\mathrm{Na}_{2} \mathrm{O}\right)$ and $5 \mu \mathrm{m}$ beam diameter were used

\begin{tabular}{|c|c|c|c|c|c|c|c|c|c|c|c|c|c|}
\hline & $\mathrm{SiO}_{2}$ & $\mathrm{TiO}_{2}$ & $\mathrm{Al}_{2} \mathrm{O}_{3}$ & $\mathrm{FeO}_{\text {tot }}$ & $\mathrm{MnO}$ & $\mathrm{MgO}$ & $\mathrm{CaO}$ & $\mathrm{Na}_{2} \mathrm{O}$ & $\mathrm{K}_{2} \mathrm{O}$ & $\mathrm{P}_{2} \mathrm{O}_{5}$ & $\mathrm{Cl}$ & Total & Correlation \\
\hline \multirow[t]{10}{*}{ Lomonosovfonna, ca. AD 1900} & 49.39 & 3.07 & 12.33 & 12.94 & 0.10 & 5.02 & 9.30 & 2.84 & 0.52 & 0.72 & 0.10 & 96.29 & Grímsvötn-1903 \\
\hline & 49.85 & 3.26 & 12.47 & 12.44 & 0.31 & 5.03 & 9.47 & 2.84 & 0.50 & 0.56 & 0.31 & 96.80 & Grímsvötn-1903 \\
\hline & 49.27 & 3.20 & 12.38 & 12.86 & 0.34 & 5.05 & 9.36 & 2.56 & 0.50 & 0.55 & 0.34 & 96.10 & Grímsvötn-1903 \\
\hline & 48.00 & 3.04 & 11.80 & 13.26 & 0.26 & 4.96 & 9.30 & 2.88 & 0.57 & 0.40 & 0.26 & 94.54 & Grímsvötn-1903 \\
\hline & 48.97 & 3.07 & 12.31 & 13.40 & 0.26 & 5.08 & 9.49 & 2.94 & 0.55 & 0.39 & 0.26 & 96.56 & Grímsvötn-1903 \\
\hline & 49.21 & 3.25 & 12.59 & 13.09 & 0.16 & 5.16 & 9.22 & 2.78 & 0.52 & 0.56 & 0.16 & 96.56 & Grímsvötn-1903 \\
\hline & 48.14 & 3.37 & 12.04 & 12.92 & 0.19 & 4.87 & 9.10 & 2.78 & 0.48 & 0.76 & 0.19 & 94.79 & Grímsvötn-1903 \\
\hline & 48.65 & 2.84 & 12.09 & 12.89 & 0.29 & 5.09 & 9.44 & 2.94 & 0.52 & 0.89 & 0.29 & 95.75 & Grímsvötn-1903 \\
\hline & 48.94 & 2.91 & 11.97 & 12.21 & 0.13 & 4.92 & 9.57 & 2.93 & 0.53 & 0.47 & 0.13 & 94.63 & Grímsvötn-1903 \\
\hline & 49.37 & 3.07 & 12.12 & 13.22 & 0.19 & 5.13 & 9.41 & 2.88 & 0.53 & 0.69 & 0.19 & 96.62 & Grímsvötn-1903 \\
\hline Mean: $(n=10)$ & 48.98 & 3.11 & 12.21 & 12.92 & 0.22 & 5.03 & 9.37 & 2.84 & 0.52 & 0.60 & 0.22 & 95.86 & \\
\hline $1 \sigma$ & 0.57 & 0.16 & 0.25 & 0.37 & 0.08 & 0.09 & 0.14 & 0.11 & 0.02 & 0.16 & 0.08 & & \\
\hline
\end{tabular}

traced in sediment sequences or peat. The Hekla-1947 tephra has also been identified in a core from the Eclipse ice field, Yukon, north-western Canada, indicating a circumpolar transport pathway (Yalcin et al., 2003).

\section{Discussion and conclusions}

Transport pathways of tephras spanning the last 1000 years

Distal occurrences of some of the key tephras aid in reconstructing the main transport direction of the ash plumes (Fig. 3(a)-(d)). These maps are not intended to show the true distribution of tephras, but provide a guide to highlight those geographical areas in which there is considerable potential for tracing some of these key horizons. Some of the tephra trajectories are defined on the basis of several records; e.g. the southerly distribution of Hekla-1 (Fig. 3(a)) is delimited according to the occurrence of eruptive material within more than 10 sites in Ireland (e.g. Hall and Pilcher, 2002). According to proximal deposits, however, the main transport component of this eruption was to the north and northeast (Thorarinsson, 1967; Larsen et al., 1999), yet Hekla-1 has only been identified in two distal sites in northern Norway and within marine records off the Icelandic coast (Larsen et al., 2002; Pilcher et al., 2005; Kristjansdóttir et al., 2007; Vorren et al., 2007). This may be a feature of where tephra investigations over the last 1000 a have been conducted in recent years rather than a real absence of Hekla-1 tephra. There is a general lack of investigations in many areas, especially in large parts of Norway and northern areas. Indeed, the identification of material from the Grímsvötn-1903 eruption in Svalbard emphasises the potential for undertaking tephra investigations in far more northerly locations than previously realised. Moreover, tephra layers within sediment records from the North Atlantic ocean are almost unknown except for a few documented records of tephra fallout on ships (Thorarinsson, 1954), whereas tephras from the last millennium have been documented in several cores north of Iceland (e.g. Larsen et al., 2002). Thus it is likely that the distribution of many of the key tephras shown in Fig. 3 may be extended and, in particular, revised if more studies are conducted in key geographical areas, e.g. Denmark, southern Sweden, Norway and Finland. Fallout patterns from the recent eruptions of Askja-1875 and Hekla-1947 were originally reconstructed from observations in documentary sources (Mohn, 1878; Salmi, 1948). Recent findings of cryptotephra in peat bogs, however, have significantly increased the known distribution of these tephras (e.g. Oldfield et al., 1997; Hall and Pilcher, 2002; Pilcher et al., 2005).

Table 3 Major element chemistry of Holocene tephras from the Grímsvötn volcanic system (wt\%): Saksunarvatn Tephra (ca. 10240 cal. a BP; data from Tephrabase www.tephrabase.org); Hov Tephra (ca. 5900 cal. a BP; Wastegård, 2002), Grímsvötn-1903 (Grönvold and Jóhannesson, 1984), Grímsvötn-1922, 1934 and 1983 (Steinthorsson et al., 2000)

\begin{tabular}{|c|c|c|c|c|c|c|c|c|c|c|}
\hline Oxide & $\begin{array}{c}\text { Saksunarvatn } \\
\text { tephra }(n=71)\end{array}$ & $1 S D$ & $\begin{array}{l}\text { Hov tephra } \\
\quad(n=11)\end{array}$ & $1 S D$ & $\begin{array}{c}G-1903 \\
(n=?)\end{array}$ & $\begin{array}{c}G-1922 \\
(n=2)\end{array}$ & $\begin{array}{c}G-1934 \\
(n=3)\end{array}$ & $\begin{array}{c}G-1983 \\
(n=2)\end{array}$ & $\begin{array}{l}\text { Lomonsovfonna, } \\
\qquad(n=10)\end{array}$ & $1 S D$ \\
\hline $\mathrm{TiO}_{2}$ & 2.97 & 0.33 & 3.14 & 0.23 & 2.92 & 2.81 & 2.70 & 2.85 & 3.11 & 0.16 \\
\hline $\mathrm{Al}_{2} \mathrm{O}_{3}$ & 13.00 & 0.46 & 12.44 & 0.27 & 13.10 & 13.87 & 13.49 & 13.45 & 12.21 & 0.25 \\
\hline $\mathrm{FeO}_{\text {tot }}$ & 14.20 & 1.16 & 14.19 & 0.42 & 13.60 & 14.99 & 14.82 & 15.23 & 12.92 & 0.37 \\
\hline $\mathrm{MnO}$ & 0.25 & 0.04 & 0.29 & 0.19 & 0.20 & 0.22 & 0.22 & 0.23 & 0.22 & 0.08 \\
\hline $\mathrm{MgO}$ & 5.51 & 0.40 & 4.68 & 0.61 & 5.45 & 5.13 & 5.68 & 5.22 & 5.03 & 0.09 \\
\hline $\mathrm{CaO}$ & 9.97 & 0.52 & 9.47 & 0.28 & 10.30 & 9.91 & 10.17 & 9.63 & 9.37 & 0.14 \\
\hline $\mathrm{Na}_{2} \mathrm{O}$ & 2.84 & 0.45 & 2.75 & 0.26 & 2.53 & 3.04 & 2.92 & 3.14 & 2.84 & 0.11 \\
\hline $\mathrm{K}_{2} \mathrm{O}$ & 0.43 & 0.07 & 0.44 & 0.04 & 0.38 & 0.45 & 0.40 & 0.48 & 0.52 & 0.02 \\
\hline $\mathrm{P}_{2} \mathrm{O}_{5}$ & - & & - & & 0.27 & 0.29 & 0.28 & 0.29 & 0.60 & 0.16 \\
\hline $\mathrm{Cl}$ & - & & - & & - & - & & - & 0.22 & 0.08 \\
\hline Mean & 95.86 & & 96.60 & & 98.55 & 100.46 & 99.56 & 100.25 & 95.86 & \\
\hline
\end{tabular}


Although there are certain distal areas that have as yet not been investigated in detail, there are a number of sites that have been examined and within which no tephra horizons were identified. These include several sites in Britain, which fall close to or within the limits of the ash plume as reconstructed from distal occurrences. For instance, tephra from the Hekla1947 eruption has been identified in Ireland and southern Finland, but not in sites in Britain that fall below the reconstructed path of the ash plume according to Fig. 3(d). It has been suggested that precipitation may play an important role in ash deposition and that the absence of Hekla-1947 in British deposits may simply be linked to precipitation patterns during the eruption. The important mid-Holocene Hekla-4 tephra also has an irregular distribution on the British Isles and is scarce or absent in areas where dry deposition is suggested (Chambers et al., 2004; Langdon and Barber, 2004). This observed phenomenon, however, may also be due to the complex nature of tephra dispersal. The eruption of Grímsvótn in 2004, and to some extent Hekla-1947, exemplifies the complex nature of tephra dispersal and highlights that transport is not always in clearly defined straight lines.

Grímsvötn is the most active volcanic system on Iceland, accounting for about $38 \%$ of the verified historical eruptions (Thordarsson and Larsen, 2007). The most recent eruption, in November 2004, injected up to $14 \mathrm{~km}$ into the atmosphere and lasted for 4 days. The first vigorous phase lasted from the evening of 1 November until the morning of 3 November, and a second, low-intensity phase continued until the evening of 4 November (Sigmundsson and Gudmundsson, 2004). Dispersion models from Volcanic Ash Advisory Centres (VAAC) show strong similarities and show that the ash plume from the first vigorous eruption phase was arcing over the Norwegian Sea, reaching as far as northern Finland, but not as far north as Svalbard (Witham et al., 2007). These models also forecast that the ash plume circled over eastern Europe and the Black Sea. Less agreement was achieved by dispersion models for the second phase, but most show high concentration of ash over the North Sea extending to Scotland, but also ash clouds with lower concentrations over northeastern Greenland and Svalbard (Witham et al., 2007). The dispersion models show the complex nature of tephra dispersal and that even a relatively small and short-lived eruption such as the 2004 eruption of Grímsvötn might produce tephra fallout over vast geographical areas. As yet, the dispersion models have not been validated by physical evidence of tephra fallout outside Iceland and only a few satellite images of the eruption plume were obtained due to overcast conditions over the North Atlantic (Witham et al., 2007). However, these dispersion models provide important information on the nature of a contemporary volcanic eruption in Iceland and demonstrate that the absence of tephra in a particular area, considered to be within the main dispersal area, may be due to the arcing nature of the ash plume rather than assuming simplified transport in a straight line.

\section{Site-specific processes and tephra deposition}

Although the complex nature of transport pathways are identified as playing a key part in the deposition of tephra, several studies also show that distal tephras often have an uneven distribution due to site-specific processes (e.g. Davies et al., 2001; Pyne-O'Donnell et al., 2008). In particular, sitespecific processes may have contributed to the patchy distribution and low shard concentrations of some of the tephras identified in Table 1. For instance, in Scandinavia a large part of the precipitation occurs as snow during the winter months and post-depositional processes associated with fallout on the snow cover, such as redeposition by wind and meltwater, may result in patches of tephra in hollows on the peat surface (Bergman et al., 2004). Thus it is quite possible that some tephras may be missed in studies that tend to focus on one recovered core or monolith. Furthermore, the role of snow beds in the catchment may play a part in the reworking of tephra deposits. Slow release of tephra trapped in catchment snow beds has been suggested as a cause for delayed tephra deposition in alpine lakes in Scandinavia (Davies et al., 2007). Only a few studies have looked in detail at the deposition of tephra in lacustrine environments in distal areas (PyneO'Donnell et al., 2008), and it has been shown that reworking of tephra from lake catchments can occur for several hundred years after the primary airfall (e.g. Davies et al., 2007). This has important implications for pinpointing the stratigraphic position of a tephra horizon that represents primary airfall, particularly as tephras are used for correlation purposes and for construction of age-depth models. This can, however, be especially difficult in lake sediment sequences due to reworking, bioturbation or even downward migration due to density-induced settling of tephra particles through organic sediments (Beierle and Bond, 2002).

\section{Basaltic tephra horizons in distal areas}

The almost complete lack of basaltic tephra in distal deposits in northern Europe is striking. So far, the only recorded distal basaltic tephra layers from the last millennium are from the eruptions of Veiðivötn-1477 (two sites), Laki-1783 and Grímsvötn-1903 (both in Lomonosovfonna, Svalbard). It has been suggested that this may be due to the origin of basaltic material from (with a few important exceptions such as the early Holocene Saksunarvatn Tephra) less explosive volcanism (Dugmore et al., 1995). Alternatively, it may be possible that basaltic shards have been affected by post-deposition dissolution (Pollard et al., 2003; Pollard and Heron, 2008). WolffBoenisch et al. (2004) showed that rhyolitic glass has an expected lifetime of $\sim 10$ times longer than basaltic glass at $\mathrm{pH}$ 4 and $25^{\circ} \mathrm{C}$. All distal occurrences of basaltic material have been found in lake sediments or ice, and basaltic tephras from the last millennium have yet to be identified in peat deposits. There is even a distinct absence of basaltic material within relatively proximal areas such as the Faroe Islands (Wastegård, unpublished), even though many documentary records from this area report tephra fallout from basaltic eruptions (Thorarinsson, 1981). Although it is clear that a number of factors influence the deposition and preservation of tephra horizons (see above), the distinct absence of basaltic horizons may be a post-depositional stability issue. Rhyolitic tephra is thought to be generally more stable than basaltic tephra, which could be affected by chemical alteration or even complete dissolution in an acid environment, such as blanket peat (Pollard et al., 2003). Peat accumulation is relatively slow on the Faroe Islands (Persson, 1968; Shotyk et al., 2005) and basaltic glass would have been exposed to acid conditions for prolonged intervals.

\section{Utilising the tephrochronology framework for the last 1000 years}

Detailed tephrochronology frameworks are of great value for palaeoenvironmental studies in areas distal to the volcanic centres. In northwestern Europe this has been especially successful in Ireland, where several historical tephras are present in lowland peats (Hall and Pilcher, 2002; Hall and 
Mauquoy, 2005). Layers such as Hekla-1 and Öræfajökull1362 are often well constrained and greatly improve the chronological control of peat profiles investigated for palaeoenvironmental studies. Ireland is probably the most studied area with regard to distal tephrochronology in Europe, but recent investigations show the potential for similar studies also in Scandinavia (e.g. Bergman et al., 2004; Boygle, 2004; Pilcher et al., 2005; Davies et al., 2007; Vorren et al., 2007; Borgmark and Wastegård, 2008). For instance, historically dated distal tephras from the last millennium have been used to constrain age-depth models and for validation of other dating methods, e.g. ${ }^{210} \mathrm{~Pb}$ dating and SCP counting (Oldfield et al., 1997; Schoning et al., 2005). The Askja-1875 and Hekla-1947 tephras also have great potential for validation of age-depth models based on short-lived radioisotopes (e.g. Oldfield et al., 1997; Davies et al., 2007).

Of the tephra layers that form the framework for the last $1000 \mathrm{a}$, at least five of the tephras (MOR-T4, BGMT-1, GB4-50, SLU-5 and QUB-384) have only been identified as discrete volcanic events based on their occurrence within distal areas and have as yet no known proximal sources in Iceland. These events have not been correlated with proximal deposits that form the basis for the Icelandic tephrochronological framework (e.g. Haflidason et al., 2000; Larsen and Eiríksson 2008). Tentative correlations can be made, but the data are too scant to allow for more secure correlations. It is often difficult to pinpoint exactly the source of the eruption, especially where only limited data exist, possibly representing only parts of the eruption. Distal sites are clearly becoming increasingly important for obtaining the most comprehensive history of volcanic events and indeed for highlighting those events that have the potential to be used as isochronous marker horizons. As a result, the framework outlined in Table 1 is continuously being updated, based on the work undertaken in distal areas, as demonstrated here by the most recent addition of the Grímsvötn 1903 eruption.

Acknowledgements We are grateful to the following persons for collaboration and stimulating discussions on last millennium tephras in northwestern Europe: Jonas Bergman, Rolf Guttesen, Valerie Hall, Elisabeth Isaksson, Gudrun Larsen and Jon Pilcher. Elisabeth Isaksson provided samples from the Lomonosovfonna ice core. Helen Ward provided technical support. Simon Blockley and John Lowe are thanked for their constructive review of the paper. This paper is a contribution to the Millennium project (EU 6th Framework), ref. no 017008-2.

\section{References}

Beierle B, Bond J. 2002. Density-induced settling of tephra through organic lake sediments. Journal of Paleolimnology 28: 433-440.

Bergman J, Wastegård S, Hammarlund D, Wohlfarth B, Roberts SJ. 2004. Holocene tephra horizons at Klocka Bog, west-central Sweden: aspects of reproducibility in subarctic peat deposits. Journal of Quaternary Science 19: 241-249.

Boer W, van den Bergh GD, de Haas H, de Stigter HC, Gleles R, van Weering TCE. 2006. Validation of accumulation rates in Teluk Banten (Indonesia) from commonly applied $\mathrm{Pb}-210$ models, using the 1883 Krakatau tephra as time marker. Marine Geology 227: 263-277.

Borgmark A, Wastegård S. 2008. Regional and local patterns of peat humification in three raised peat bogs in Värmland, south-central Sweden. GFF 130: 161-176.

Boygle J. 1999. Variability of tephra in lake and catchment sediments, Svínavatn, Iceland. Global and Planetary Change 21: 129-149.

Boygle J. 2004. Towards a Holocene tephrochronology for Sweden: geochemistry and correlation with the North Atlantic tephra stratigraphy. Journal of Quaternary Science 19: 103-109.
Chambers FM, Daniell JRG, Hunt JB, Molloy K, O'Connell M. 2004. Tephrostratigraphy of An Loch Mór, Inis Oírr, western Ireland: implications for Holocene tephrochronology in the northeastern Atlantic region. The Holocene 14: 703-720.

Clausen HB, Hammer CU. 1988. The Laki and Tambora eruptions as revealed in Greenland ice cores from 11 locations. Annals of Glaciology 10: 16-22.

Connell A. 1846. Analysis of the volcanic dust which fell in the Orkney Islands on 2nd of October 1845. New Edinburgh Philosophical Journal 40: 217-219.

Davies S, Turney CSM, Lowe JJ. 2001. Identification and significance of a visible, basalt-rich Vedde Ash layer in a Late-glacial sequence on the Isle of Skye, Inner Hebrides, Scotland. Journal of Quaternary Science 16: 99-104.

Davies SM, Elmquist M, Bergman J, Wohlfarth B, Hammarlund D. 2007. Cryptotephra sedimentation processes within two lacustrine sequences from west central Sweden. The Holocene 17: 319-330.

Dugmore A. 1989. Icelandic volcanic ash in Scotland. Scottish Geographical Magazine 105: 168-172.

Dugmore AJ, Newton AJ. 1998. Holocene tephra layers in the Faroe Islands. Fróðskaparrit 46: 191-204.

Dugmore AJ, Larsen G, Newton AJ. 1995. Seven tephra isochrones in Scotland. The Holocene 5: 257-266.

Dugmore AJ, Newton AJ, Edwards KJ, Larsen G, Blackford JJ, Cook GT. 1996. Long-distance marker horizons from small-scale eruptions: British tephra deposits from the AD 1510 eruption of Hekla, Iceland. Journal of Quaternary Science 11: 511-516.

Dugmore AJ, Church MJ, Mairs KA, McGovern TH, Perdikaris S, Vesteinsson O. 2007. Abandoned farms, volcanic impacts, and woodland management: revisiting Pjórsárdalur, the 'Pompeii of Iceland'. Arctic Anthropology 44: 1-11.

Eiríksson J, Knudsen KL, Haflidason H, Heinemeier J. 2000. Chronology of late Holocene climatic events in the northern North Atlantic based on AMS ${ }^{14} \mathrm{C}$ dates and tephra markers from the volcano Hekla, Iceland. Journal of Quaternary Science 15: 573-580.

Fiacco RJ, Thordarson T, Germani MS, Self S, Palais JM, Whitlow S, Grootes PM. 1994. Atmospheric aerosol loading and transport due to the 1783-84 Laki eruption in Iceland, interpreted from ash particles and acidity in the GISP2 ice core. Quaternary Research 42: 231-240.

Goslar T, van der Knaap WO, Hicks S, Andric M, Czernik J, Goslar E, Räsänen S, Hyötylä H. 2005. Radiocarbon dating of modern peat profiles: pre- and post-bomb C-14 variations in the construction of age-depth models. Radiocarbon 47: 115-134.

Grönvold K, Jóhannesson H. 1984. Eruption in Grímsvötn; course of events and chemical studies of tephra. Jökull 34: 1-8.

Haflidason H, Eiríksson J, van Krefeld S. 2000. The tephrochronology of Iceland and the North Atlantic region during the Middle and Late Quaternary: a review. Journal of Quaternary Science 15: 3-22.

Hall VA. 2003. Vegetation history of mid- to western Ireland in the 2nd millennium AD: fresh evidence from tephra-dated palynological investigations. Vegetation History and Archaeobotany 12: 7-17.

Hall VA, Mauquoy D. 2005. Tephra-dated climate- and human-impact studies during the last 1500 years from a raised bog in central Ireland. The Holocene 15: 1086-1093.

Hall VA, Pilcher JR. 2002. Late Quaternary Icelandic tephras in Ireland and Great Britain: detection, characterisation and usefulness. The Holocene 12: 223-230.

Isaksson E, Pohjola V, Jauhiainen T, Moore J, Pinglot JM, Vaikmäe R, van de Wal RSW, Hagen JO, Ivask J, Karlöf L, Martma T, Meijer HAJ, Mulvaney R, Thomassen M, van den Broeke M. 2001. A new ice-core record from Lomonosovfonna, Svalbard: viewing the 1920-97 data in relation to present climate and environmental conditions. Journal of Glaciology 47: 335-345.

Kekonen T, Moore J, Perämäki P, Martma T. 2005. The Icelandic Laki volcanic tephra layer in the Lomonosovfonna ice core, Svalbard. Polar Research 24: 33-40.

Kirkbride MP, Dugmore AJ. 2003. Glaciological response to distal tephra fallout from the 1947 eruption of Hekla, south Iceland. Journal of Glaciology 49: 420-428.

Kristjansdóttir GB, Stoner JS, Jennings AE, Andrews JT, Grönvold K. 2007. Geochemistry of Holocene cryptotephras from the North Iceland Shelf (MD99-2269): intercalibration with radiocarbon and palaeomagnetic chronostratigraphies. The Holocene 17: 155-176. 
Langdon PG, Barber KE. 2001. New Holocene tephras and proxy climate record from a blanket mire in northern Skye, Scotland. Journal of Quaternary Science 16: 753-759.

Langdon PG, Barber KE. 2004. Snapshots in time: precise correlations of peat-based proxy climate records in Scotland using mid-Holocene tephras. The Holocene 14: 21-33.

Larsen G. 1981. Tephrochronology by microprobe glass analysis. In Tephra Studies: Proceedings of the NATO Advanced Study Institute 'Tephra Studies as a Tool in Quaternary Research', Self S, Sparks RSJ (eds). Reidel: Dordrecht; 95-102.

Larsen G. 1984. Recent volcanic history of the Veidivötn fissure swarm, southern Iceland: an approach to volcanic risk assessment. Journal of Volcanology and Geothermal Research 22: 33-58.

Larsen G, Eiríksson J. 2008. Late Quaternary terrestrial tephrochronology of Iceland: frequency of explosive eruptions, type and volume of tephra deposits. Journal of Quaternary Science 23: 109-120.

Larsen G, Thorarinsson S. 1977. H4 and other acid Hekla tephra layers. Jökull 27: 28-46.

Larsen G, Dugmore A, Newton A. 1999. Geochemistry of historical-age silicic tephras in Iceland. The Holocene 9: 463-471.

Larsen G, Newton AJ, Dugmore AJ, Vilmundardóttir EG. 2001. Geochemistry, dispersal, volumes and chronology of Holocene silicic tephra layers from the Katla volcanic system, Iceland. Journal of Quaternary Science 16: 119-132.

Larsen G, Eiríksson J, Knudsen KL, Heinemeier J. 2002. Correlation of late Holocene terrestrial and marine tephra markers, north Iceland: implications for reservoir age changes. Polar Research 21: 283-290.

Le Maitre RW. 1984. A proposal by the IUGS subcommission on the systematics of igneous rocks for a chemical classification of volcanic rocks based on the total alkali silica (TAS) diagram. Australian Journal of Earth Sciences 31: 243-255.

Mohn H. 1878. Askeregnen den 29de-30te Marts 1875. Forhandlinger $i$ Videnskapsselskabet i Christania aar 1877 10: 1-13.

Óladottir BA, Sigmarsson O, Larsen G, Thordarson T. 2008. Katla volcano, Iceland: magma composition, dynamics and eruption frequency as recorded by Holocene tephra layers. Bulletin of Volcanology 70: 475-493.

Oldfield F. 2005. Environmental Change. Cambridge University Press: Cambridge, UK.

Oldfield F, Thompson R, Crooks PRJ, Gedye SJ, Hall VA, Harkness DD, Housley RA, McCormac FG, Newton AJ, Pilcher JR, Renberg I, Richardson N. 1997. Radiocarbon dating of a recent high-latitude peat profile: Stor Åmyrân, northern Sweden. The Holocene 7: 283290.

Palais J, Mayewski PA, Taylor K, Grootes PM. 1991. Volcanic ash from the 1362 AD Oraefajokull eruption (Iceland) in the Greenland ice sheet. Geophysical Research Letters 18: 1241-1244.

Persson C. 1966. Försök till tefrokronologisk datering av några svenska torvmossar. Geologiska Föreningens i Stockholm Förhandlingar 88: 361-395.

Persson C. 1967. Försök till tefrokronologisk datering i tre norska myrar. Geologiska Föreningens i Stockholm Förhandlingar 89: 181-197.

Persson C. 1968. Försök till tefrokronologisk datering i fyra färöiska myrar. Geologiska Föreningens i Stockholm Förhandlingar 90: 241266.

Pilcher JR, Hall VA. 1992. Towards a tephrochronology for the Holocene of the north of Ireland. The Holocene 2: 255-259.

Pilcher JR, Hall VA, McCormac FG. 1995. Dates of Holocene Icelandic volcanic eruptions from tephra layers in Irish peats. The Holocene $\mathbf{5}$ : 103-110.

Pilcher JR, Hall VA, McCormac FG. 1996. An outline tephrochronology for the Holocene of the north of Ireland. Journal of Quaternary Science 11: 485-494.

Pilcher J, Bradley RS, Francus P, Anderson L. 2005. A Holocene tephra record from the Lofoten Islands, Arctic Norway. Boreas 34: 136-156.

Pollard AM, Heron C. 2008. Archaeological Chemistry. RSC Publishing: Cambridge, UK.

Pollard AM, Blockley SPE, Ward KR. 2003. Chemical alteration of tephra in the depositional environment: theoretical stability modelling. Journal of Quaternary Science 18: 385-394.

Pyne-O'Donnell SDF, Blockley SPE, Turney CSM, Lowe JJ. 2008. Distal volcanic ash layers in the Lateglacial Interstadial (GI-1): problems of stratigraphic discrimination. Quaternary Science Reviews 27: 72-84.
Salmi M. 1948. The Hekla ashfalls in Finland AD1947. Bulletin de la Commission géologique de Finlande 142: 87-96.

Schoning K, Charman D, Wastegård S. 2005. Reconstructed water tables from two ombrotrophic mires in eastern central Sweden compared with instrumental meteorological data. The Holocene 15: 111-118.

Schwikowski M, Doscher A, Gaggeler HW, Schotterer U. 1999. Anthropogenic versus natural sources of atmospheric sulphate from an Alpine ice core. Tellus Series B - Chemical and Physical Meteorology 51: 938-951.

Selbekk RS, Trønnes RG. 2007. The 1362 AD Öræfajökull eruption, Iceland: petrology and geochemistry of large-volume homogeneous rhyolite. Journal of Volcanology and Geothermal Research 160: 4258.

Shotyk W, Chen B, Krachler M. 2005. Lithogenic, oceanic and anthropogenic sources of atmospheric $\mathrm{Sb}$ to a maritime blanket bog, Myrarnar, Faroe Islands. Journal of Environmental Monitoring 7: 1148-1154.

Sigmundsson F, Gudmundsson MT. 2004. Gos í Grímsvötunum 1.-6 nóvember 2004. Jökull 54: 135-138.

Sigvaldason G. 2002. Volcanic and tectonic processes coinciding with glaciation and crustal rebound: an early Holocene rhyolitic eruption in the Dyngufjöll volcanic centre and the formation of the Askja caldera, north Iceland. Bulletin of Volcanology 64: 192205.

Steinthorsson S, Hardarson BS, Ellam RM, Larsen G. 2000. Petrochemistry of the Gjálp-1996 subglacial eruption, Vatnajökull, SE Iceland. Journal of Volcanology and Geothermal Research 98: 7990.

Stihler SD, Stone DB, Beget JE. 1992. Varve counting vs tephrochronology and Cs-137 and Pb-210 dating: a comparative test at Skilak Lake, Alaska. Geology 20: 1019-1022.

Stothers RB. 1996. The great dry fog of 1783. Climatic Change 32: 79-89.

Swindles GT. 2006. Reconstructions of Holocene climate change from peatland in the north of Ireland. PhD thesis, Queen's University, Belfast.

Sylvester AG. 1975. History and surveillance of volcanic activity on Jan Mayen island. Bulletin of Volcanology 39: 313-335.

Thorarinsson S. 1944. Tefrokronologiska studier på Island. Geografiska Annaler 26: 1-217.

Thorarinsson S. 1951. Laxárgljúfur and Laxárhraun: a tephrochronological study. Geografiska Annaler 1-2: 1-89.

Thorarinsson S. 1954. The tephra fall from Hekla on March 291947. The Eruption of Hekla 1947-1948 2(3): 1-68. Societas Scientarium Islandica.

Thorarinsson S. 1958. The Öræfajökull eruption of 1362. Acta Naturalia Islandica 2: 1-99.

Thorarinsson S. 1967. The eruptions of Hekla in historical times. The Eruption of Hekla 1947-19481: 1-183. Societas Scientarium Islandica.

Thorarinsson S. 1981. Greetings from Iceland, ashfalls and volcanic aerosols in Scandinavia. Geografiska Annaler 63A: 109-118.

Thorarinsson S, Sæmundsson K. 1979. Volcanical activity in historical time. Jökull 29: 29-32.

Thordarson T, Larsen G. 2007. Volcanism in Iceland in historical time: volcano types, eruption styles and eruptive history. Journal of Geodynamics 43: 118-152.

Thordarson T, Self S. 2003. Atmospheric and environmental effects of the 1783-1784 Laki eruption: a review and reassessment. Journal of Geophysical Research 108(D1), 4011, doi: 10.1029/2001JD002042. van den Bogaard C, Schmincke H-U. 2002. Linking the North Atlantic to central Europe: a high resolution Holocene tephrochronological record from northern Germany. Journal of Quaternary Science 17: 320 .

Vorren K-D, Blaauw M, Wastegård S, van der Plicht J, Jensen $\mathrm{CAH}$. 2007. High-resolution stratigraphy of the northernmost concentric raised bog in Europe: Sellevollmyra, Andøya, northern Norway. Boreas 36: 253-277.

Wastegård S. 2002. Early to Middle Holocene silicic tephra horizons from the Katla volcanic system, Iceland: new results from the Faroe Islands. Journal of Quaternary Science 17: 723-730.

Wastegård S, Hall VA, Hannon GE, van den Bogaard C, Pilcher JR, Sigurgeirsson MÁ, Hermanns-Audardóttir M. 2003. Rhyolitic tephra horizons in northwestern Europe and Iceland from the AD 700s- 
800s: a potential alternative for dating first human impact. The Holocene 13: 277-283.

Witham CS, Oppenheimer C. 2004. Mortality in England during the 1783-4 Laki Craters eruption. Bulletin of Volcanology 67: 15-26.

Witham CS, Hort MC, Potts R, Servranckx R, Husson P, Bonnardot F. 2007. Comparison of VAAC atmospheric dispersion models using the 1 November 2004 Grimsvötn eruption. Meteorological Applications 14: $27-38$.

Wolff-Boenisch D, Gislason SR, Oelkers EH, Putnis CV. 2004. The dissolution rates of natural glasses as a function of their composition at $\mathrm{pH} 4$ and 10.6, and temperatures from 25 to 74 degrees $\mathrm{C}$. Geochimica et Cosmochimica Acta 68: 4843-4858.

Yalcin K, Wake CP, Germani MS. 2003. A 100-year record of North Pacific volcanism in an ice core from Eclipse Icefield, Yukon Territory, Canada. Journal of Geophysical Research 108(D1), 4012, doi: 10.1029/2002JD002449.

Zielinski GA, Mayewski PA, Meeker LD, Whitlow S, Twickler MS, Morrison M, Meese DA, Gow AJ, Alley RB. 1994. Record of volcanism since 7000 BC from the GISP2 Greenland ice core and implications for the volcano-climate system. Science 264: 948-952. 